\title{
A tradução infinita ${ }^{1}$
}

\section{The infinite translation}

Raúl Antelo*

\begin{abstract}
RESUMO
Justapondo-se as traduções de dois textos de Borges (Queja de todo criollo e Borges y yo) por dois escritores brasileiros de tempos distintos (Mário de Andrade e Clarice Lispector), postula-se a noção de "tradução infinita", ancorada teoricamente na leitura que Deleuze e Guatarri fazem dos espaços riemannianos, como marca da escritura e da autoria em tempos de hipermodernidade.
\end{abstract}

\section{ABSTRACT}

Comparing translations for two Borges' texts (Queja de todo criollo and Borges y yo) made by two brazilian authors in different moments of history, one may postulate the notion of "infinite translation", theoretically sustained by the reading that Deleuze and Guatarri have done of the riemannian spaces, such as the writing mark and the authorship in hipermodern times.

1 Tradução de Iamni Reche Bezerra.

* $\mathrm{UFSC} / \mathrm{CNPq}$ 


\section{Antelo, R. A tradução infinita}

O autor marca o ponto em que uma vida foi jogada na obra. Jogada, não expressa; jogada, não realizada. Por isso, o autor nada pode fazer além de continuar, na obra, não realizado e não dito. Ele é o ilegível que torna possivel a leitura, o vazio lendário de que procedem a escritura e o discurso.

O gesto do autor é atestado na obra a que também dá vida, como uma presença incongruente e estranha, exatamente como, segundo os teóricos da comédia de arte, a trapaça de Arlequim incessantemente interrompe a história que se desenrola na cena, desfazendo obstinadamente a sua trama.

Giorgio Agamben - "O autor como gesto" in Profanações
$\mathrm{J}$

á se sabe que a tradução ocupa um lugar proeminente na obra de Borges. O escritor faz referência a ela em diversas ocasiões. As mais conhecidas são "Las versiones homéricas" e "Los traductores de las 1001 noches"; mas é em um, até há pouco esquecido, artigo de 1926, "Las dos maneras de traducir", que Borges formula suas primeiras apreciações sobre o tema. O ponto de vista é explícito:

Universalmente, supongo que hay dos clases de traducciones. Una practica la literalidad, la otra la perífrasis. La primera corresponde a las mentalidades románticas, la segunda a las clásicas. Quiero razonar esta afirmación, para disminuirle su aire de paradoja. A las mentalidades clásicas les interesará siempre la obra de arte y nunca el artista. Creerán en la perfección absoluta y la buscarán. Desdeñaran los localismos, las rarezas, las contingencias. ¿No ha de ser la poesía una hermosura semejante a la luna: eterna, desapasionada, imparcial? La metáfora, por ejemplo, no es considerada por el clasicismo ni como énfasis ni como una visión personal, sino como una obtención de verdad poética, que, una vez agenciada, puede (y debe) ser aprovechada por todos. Cada literatura posee un

Revista Letras, Curitiba, UFPR, n. 95 182-202, jan./jun. 2017. ISSN 2236-0999 (versão eletrônica) 
repertorio de esas verdades, y el traductor sabrá aprovecharlo y verter su original no sólo a las palabras, sino a la sintaxis y a las usuales metáforas de su idioma.

Esse procedimento - diz Borges - nos parece sacrilégio, adiantando o tema da leitura literal como procedimento da religião e dos notários. Ou seja, o ideal de tradução borgeana assemelha-se com a profanação textual de Agamben. Como típico martinfierrista, o escritor condena a metáfora, mesmo sabendo que "la mayoría de las metáforas ya no son representaciones, son maquinales". Ao seu modelo, clássico, mas profanador, da tradução, contrapõe então o romântico, recordando que "los románticos no solicitan jamás la obra de arte, solicitan el hombre".

Y el hombre (ya se sabe) no es intemporal ni arquetípico, es Diego Fulano, no Juan Mengano, es poseedor de un clima, de un cuerpo, de una ascendencia, de un hacer algo, de un no hacer nada, de un presente, de un pasado, de un porvenir y hasta de una muerte que es suya. ¡Cuidado con torcerle una sola palabra de las que dejó escritas!

Esa reverencia del yo, de la irreemplazable diferenciación humana que es cualquier yo, justifica la literalidad en las traducciones. Además, lo lejano lo forastero, es siempre belleza. Novalis ha enunciado con claridad ese sentimiento romántico: La filosofía lejana resuena como poesía. Todo se vuelve poético en la distancia: montes lejanos, hombres lejanos, acontecimientos lejanos y lo demás. De eso deriva lo esencialmente poético de nuestra naturaleza. Poesía de la noche y de la penumbra (Werke, III, 213). Gustación de la lejanía, viaje casero por el tiempo y por el espacio, vestuario de destinos ajenos, nos son prometidos por las traslaciones literarias de obras antiguas: promesa que suele quedarse en el prólogo.

Assim, Borges assinala o paradoxo de que, segundo o propósito anunciado de veracidade (e não de verossimilhança) literária, o tradutor torna-se um falsário, porque, "para mantener la extrañez de lo que traduce se ve obligado a espesar el color local, a encrudecer las crudezas, a empalagar con las dulzuras y a enfatizarlo todo hasta la mentira”. Uma vez desconstruída a fronteira entre verdade e falsidade, não lhe sobra mais do que derrubar o muro entre o próprio e o alheio, argumentando, assim, que:

En cuanto a las repetidas versiones de libros famosos, que han fatigado y siguen fatigando las prensas, sospecho que su 

Antelo, $\mathrm{R}$.
A tradução
infinita
Revista Letras,

Curitiba, UFPR, n. 95 182-202, jan./jun. 2017. ISSN 2236-0999 (versão eletrônica) finalidad verdadera es jugar a las variantes y nada más. A veces, el traductor aprovecha los descuidos o los idiotismos del texto para verle comparaciones. Este juego, bien podría hacerse dentro de una misma literatura. ¿A qué pasar de un idioma a otro? Es sabido que el Martín Fierro empieza con estas rituales palabras: "Aquí me pongo a cantar - al compás de la vigüela”. Traduzcamos con prolija literalidad: "En el mismo lugar donde me encuentro, estoy empezando a cantar con guitarra”, y con altisonante perífrasis: "Aquí, en la fraternidad de mi guitarra, empiezo a cantar", y armemos luego una documentada polémica para averiguar cuál de las dos versiones es peor. La primera, ¡tan ridícula y cachacienta!, es casi literal. ${ }^{2}$

Desconhecedor, evidentemente, desse debate, Mário de Andrade empreendeu em 1928 a tradução de uma das Inquisições de Borges. Não era completamente neófito quanto aos problemas éticos implicados na tradução. Havia lido, entre outras coisas, as ideias desenvolvidas por Borges em sua inquisição de 1922, "La nadería de la personalidad", retomadas no ensaio citado acima, e conhecia também a opinião do escritor em relação ao trabalho de Fitzgerald como tradutor de Omar Khayam, que havia imitado, mais que traduzido, os rapsódicos poemas do poeta persa. Mário de Andrade, que na ocasião estava justamente fazendo o mesmo com relatos etnográficos brasileiros, dos quais em pouco tempo nos ofereceria um deslumbrante resultado em Macunaíma, esse grande não-livro que seu próprio autor não julgava romance senão poema, antologia folclórica, scherzo e até mesmo sintoma, mas não símbolo, de uma literatura nacional que os modernistas estavam construindo, Mário de Andrade, digo, ensaia traduzir "Quejas de todo criollo", uma inquisição de pouca fortuna na crítica argentina.

A escolha já é por si mesma eloquente. Os martinfierristas, como sabemos, se dedicaram, em diversos estilos, a uma ontologia nacional. Queriam atingir a antropogênese do criollo, resgatar a contribuição intelectual da América Latina, prévia tesourada a todo cordão umbilical, como pedia Oliverio Girondo no manifesto da revista Martín Fierro, para se sentirem criollos em qualquer lugar, sem nostalgia de nenhuma pátria a não ser a humana, como ansiava Antonio Vallejo $^{3}$,- ou simplesmente, para fazer literatura, como concebia Borges, "con sabor de patria, como guitarra que sabe a soledades y a campo y a poniente detrás de un trebolar...". A metafísica nacional se adaptava muito bem a essa estratégia estética porque lhes construía uma ponte para além do animal, em direção à história humana, ocidental. Admitindo, então, que a tradição ocidental

2 BORGES, Jorge Luis - "Las dos maneras de traducir" in Textos recobrados 1919-1929, Barcelona, Emecé Editores, 1997, p.257-259.

3 VALLEJO, Antonio - "Criollismo y metafísica”. Martin Fierro, nº 27-8, 10 mayo 1926, p.17.

4 BORGES, Jorge Luis - Inquisiciones, Buenos Aires, Proa, 1925, p.19. 
existe, que se impõe, a metafísica do ser trata de reivindicá-la como nossa, como criolla, estabelecendo assim uma borda perfurada ou entre-lugar que conserva a memória de um corte originário. Busca-se, então, a reapropriação do melhor que há nessa cultura ocidental, como arma contra o pior dela mesma, fazendo-a movimentar-se desde a nossa situação ambivalente, na qual o Ocidente se veria segundo os mestres da suspeita - como Outro de si mesmo. A identidade criolla seria assim a constante construção de uma diferença, que é também a busca, em si mesma, de um modo sul-americano de ser universal.

Ao escolher esse texto de Borges em detrimento de outros, mais revisitados pela crítica local, Andrade revela compreender que traduzir um autor é converter intensidades que nos chegam de uma forma singular, irrepetível, mas que, de certo modo, produzem um rastro, deixam um buraco em seu leitor, que deverá encontrar, a seu modo, uma nova forma em sua língua, o que equivale, segundo Benjamin, a captar o modo-de-dizer do original, ou talvez, o modo de repetir do original.

Transcrevamos, então, as duas versões do lamento.

\section{QUEJA DE TODO CRIOLLO}

Muestran las naciones dos índoles: una la obligatoria, de convención, hecha de acuerdos con los requerimientos del siglo y las más veces con el prejuicio de algún definidor famoso; otra la verdadera, entrañable, que la pausada historia va declarando y que se trasluce también por el lenguaje y las costumbres. Entre ambas índoles, la aparencial y la esencial, suele advertirse una contrariedad notoria. Así en tratándose del vulgo de Londres fuera de duda el más reverente, sumiso, desdibujado que han visto mis andanzas - es manifiesta cosa que Dickens lo celebra por lo descarado y vivaz, cualidades que si alguna vez fueron propias ya no lo son, pero que todo narrador inglés sigue mintiendo con pertinacia relajada. En lo atañedero al pueblo español, hoy concordamos todos (aconsejados por la literatura romántica y el solamente ver en su historia la empresa americana y el Dos de mayo) en la vehemencia desbocada de su carácter, sin recordar que Baltasar Gracián supo establecer una antítesis entre la tardanza española y el ímpetu francés. Traigo estos ejemplos a colación para que el juicio del leyente consienta con mayor docilidad lo que en mi alegato hubiere de extraño.

Quiero puntualizar la desemejanza insuperable que media entre el carácter verdadero del criollo y el que quieren infligir.

El criollo, a mi entender, es burlón, suspicaz, desengañado de antemano de todo y tan mal sufridor de la grandiosidad verbal 


\section{Antelo, R. \\ A tradução infinita}

que en poquísimos la perdona y en ninguno la ensalza. El silencio arrimado al fatalismo tiene eficaz encarnación en los dos caudillos mayores que abrazaron el alma de Buenos Aires: en Rosas e Irigoyen. Don Juan Manuel, pese a sus fechorías e inútil sangre derramada, fue queridísimo del pueblo. Irigoyen, pese a las mojigangas oficiales, nos está siempre gobernando. La significación que el pueblo apreció en Rosas, entendió en Roca y admira en Irigoyen, es el escarnio de la teatralidad, o el ejercerla con sentido burlesco. En pueblos de mayor avidez en el vivir, los caudillos famosos se muestran botarates y gesteros, mientras aquí son taciturnos y casi desganados. Les restaría fama provechosa el impudor verbal. Ese nuestro desgano es tan entrañable que hasta en la historia - crónica de obradores y no de pensativos - se advierte. San Martín desapareciéndose en Guayaquil, Quiroga yendo a una asechanza de inevitables y certeros puñales por puro fatalismo de bravuconería: Saraiva desdeñando una fácil entrada victoriosa en Montevideo, ejemplifican mi aserción. No es, empero, en la historia donde mejor puede tantearse la traza espiritual de una gente. Un noble instinto artístico, una tenaz indeliberación de tragedia, hacen que todo historiador pare mientes antes en lo irregular de un motín que en muchos lustros remansados y quietos de cotidianidad. También influyen las alternativas políticas. Los altibajos venideros arbitran si conviene situar mayor realidad en la protesta de Liniers o en el bochinche de un cabildo abierto. Consideremos algún otro semblante que sea más de siempre: verbigracia, nuestra lírica criolla. Todo es en ella quietación, desengaño; áspero y dulzarrón a la vez. La índole española se nos muestra como vehemencia pura; diríase que al asentarse en la pampa, se desparramó y se perdió. El habla se hizo más arrastrada, la igualdad de horizontes sucesivos chasqueó las ambiciones y el obligatorio rigor de sujetar un mundo montaraz se resarció en las dulces lentitudes de la payada de contrapunto, del truco dicharachero y del mate. Se achaparró la intensidad castellana, pero en los criollos quedó enhiesto y vivaz ese sonriente fatalismo mediante el cual las dos obras mejores de la literatura hispánica son dos ensalzamientos del fracaso: el Quijote en la prosa y la Epístola Moral en el verso. El sufrimiento, las blandas añoranzas, la burla maliciosa y sosegada, son los eviternos motivos de nuestra lírica popular. En ella no hay asombro de metáforas; la imagen brujuleada no se realiza. En la frecuente vidalita que narra, no hay rama

Revista Letras, Curitiba, UFPR, n. 95 182-202, jan./jun. 2017. ISSN 2236-0999 (versão eletrônica) 
en el monte, vidalitá, la semejanza entre el corazón herido de ausencia y la floresta maltratada por el invierno rígido, no se establece, pero es preciso vislumbrarla para penetrar en la estrofa. La eficacia de los versos gauchescos nunca se manifiesta con jactancia; no está en el ictus sententiarum, en el envión de las sentencias, que diría Séneca, sino en la fácil trabazón del conjunto.

Vea los pingos. ¡Ah, hijitos!

Son dos fletes soberanos.

Como si jueran hermanos

Bebiendo l'agua juntitos.

Murmura Estanislao del Campo con leve perfección. Lo mismo le acontece al Martín Fierro. Es conmovedora la austeridad verbal de estrofas como ésta:

Había un gringuito cautivo

Que siempre hablaba del barco

Y lo augaron en un charco

Por causante de las pestes.

Tenía los ojos celestes

Como potrillita zarco.

Significativo es asimismo el pudor por el cual Martín Fierro pasa como sobre ascuas sobre la muerte de su compañero y no quiere situarla en su relación, sino alejarla en el pasado:

De rodillas a su lao

Yo lo encomendé a Jesús.

Faltó a mis ojos la luz,

Cai como herido del rayo.

Tuve un terrible desmayo

Cuando lo vi muerto a la Cruz.

En las irrisorias coplas anónimas que se derraman de vihuela en vihuela, se trasluce también todo lo idiosincrásico del criollismo. El andaluz alcanza la jocosería mediante el puro disparate y la hipérbole; el criollo la recaba, desquebrajando una expectación, prometiendo al oyente una continuidad que infringe de golpe.

Señores, escuchenmén:

Tuve una vez un potrillo

Que de un lao era tordillo 


\section{Antelo, R. \\ A tradução infinita}

Y del otro lao, también.

A orillas de un arroyito

Vide dos toros bebiendo.

Uno era coloradito

Y el otro...salió corriendo.

Cuando la perdiz canta

Nublado viene;

No hay mejor seña de agua

Que cuando llueve.

Tampoco en Martín Fierro faltan ejemplos de contraste chasqueado:

A otros les salen las coplas

Como agua de manantial;

Pues a mí me pasa igual.

La tristura, la inmóvil burlería, la insinuación irónica, he aquí los únicos sentires que un arte criollo puede pronunciar sin dejo forastero. Muy bien está el Lugones de El Solterón y de la Quimera Lunar, pero muy mal está su altilocuencia de bostezable asustador de leyentes. En cuanto a gritadores como Ricardo Rojas, hechos de espuma y de patriotería y de insondable nada, son un vejamen paradójico de nuestra verdadera forma de ser. El público lo siente y sin entremeterse a enjuiciar su obra la deja prudencialmente de lado, anticipando y con razón que tiene mucho más de grandioso que de legible. Nadie se arriesgará a pensar que en Fernández Moreno hay más valía que en Lugones, pero toda alma nuestra se acordará mejor con la serenidad del uno que con el arduo gongorismo del otro.

Lugones, en manifiesto aprendizaje de Herrera y Reissig o Laforgue y en cauteloso aprendizaje de Goethe, es el ejemplo menos lastimoso del trance por el cual hoy pasamos todos: el del criollo que intenta descriollarse para debelar este siglo. Su dilemática tragedia es la nuestra; su triunfo es la excepción de muchos fracasos.

Se perdió el quieto desgobierno de Rosas; los caminos de hierro fueron avalorando los campos, la mezquina y logrera agricultura desdineró la fácil ganadería y el criollo, vuelto forastero en su patria, realizó en el dolor la significación hostil de los vocablos argentinidad y progreso. Ningún prolijo cabalista numerador de letras ha desplegado ante palabra
Revista Letras, Curitiba, UFPR, n. 95 182-202, jan./jun. 2017. ISSN 2236-0999 (versão eletrônica) 
alguna la reverencia que nosotros rendimos delante de esas dos. Suya es la culpa de que los alambrados encarcelen la pampa, de que el gauchaje se haya quebrantando, de que los únicos quehaceres del criollo sean la milicia o el vagamundear o la picardía, de que nuestra ciudad se llama Babel. En el poema de Hernández y en las bucólicas narraciones de Hudson (escritas en inglés, pero más nuestras que una pena) están los actos iniciales de la tragedia criolla. Faltan los postrimeros, cuyo tablado es la perdurable llanura y la visión lineal de Buenos Aires, inquietada por la movilidad. Ya la República se nos extranjeriza, se pierde. Fracasa el criollo, pero se altiva y se insolenta la patria. En el viento hay banderas; tal vez mañana a fuerza de matanzas nos entrometeremos a civilizadores del continente. Seremos una fuerte nación. Por la virtud de esa proceridad militar, nuestros grandes varones serán claros ante los ojos del mundo. Se les inventará, si no existen. También para el pasado habrá premios. Confiemos, lector, en que se acordarán de vos y de mí en ese justo repartimiento de gloria...

Morir es ley de razas y de individuos. Hay que morirse bien, sin demasiado ahinco de quejumbre, sin pretender que el mundo pierde su savia por eso y con alguna burla linda en los labios. Se me viene a ellos el ejemplo de Santos Vega y con un dejo admonitor que antes no supe verle. Morir cantando. ${ }^{5}$

\section{QUEIXAS DE TODO CRIOULO}

As nações mostram duas índoles: uma de convenção, a obrigatória, feita de acordo com as exigências do tempo e as mais das vezes com a definição preconcebida de algum célebre; outra, entranhada, a verdadeira, que a história vai desentranhando e que também transluz na fala e nos costumes. Entre essas duas índoles, a aparente e a essencial, a gentepercebe uma contradição notória. Por exemplo os praceanos de Londres: não tem dúvida que o povo mais submisso reverente e vago que observei nas minhas vagamundagens mas que a gente sabe celebrado por Dickens como vivaz e descarado. Ora se estas qualidades já foram próprias um dia do povo de Londres já não o são mais. No entanto, todo narrador inglês continua na mesma mentira com pertinácia arrelachada.

5 BORGES, Jorge Luis - "Queja de todo criollo" in Inquisiciones. Buenos Aires, Proa, 1925.p.131-138. 


\section{Antelo, R. \\ A tradução infinita}

Relativamente ao povo espanhol, olhando na história dele só a empresa americana e o Dois de Maio ou aconselhados pela literatura romântica, nós todos concordamos na veemência destabocada do caracter dele, não lembrando que Baltasar Gracián já pôde estabelecer uma antítese entre o tardonho do espanhol e o impetuoso do francês. Se ponho estes exemplos na conversa é só pra que o leitor aceite com maior docilidade o que eu falar de estranhável.

Quero especificar a dissemelhança que existe entre o caracter verdadeiro do crioulo e o que lhe querem dar.

O crioulo me parece que é troçador, desconfiado, de antemão desenganado de tudo e tão empinimado com o verbalismo que o perdoa só nuns poucos e em ninguém não o elogia. Nos dois maiores caudilhos que abraçaram a alma de Buenos Aires se encarnaram o silêncio de braço dado com o fatalismo, Rosas e Irigoyen. D. João Manuel, a pesar das façanhas e sangue inultimente derramado, foi querido do povo. Irigoyen, apesar de todas as bugigangas oficiais ainda está sempre governando a gente. A feição que o povo gostou em Rosas, entendeu em Roca e admira em Irigoyen é o debique da teatralidade ou a terem exercido só de caçoada. Entre gente de maior sofreguidão pra viver, os caudilhos famosos se mostram cheios de gestos e palavrosos ao passo que aqui são sorumbáticos e quase desenganados. A semvergonhice verbal lhes diminuiria a fama proveitosa. Este nosso desengano é tão visceral que a gente o percebe até na História - crônica de trabalhadores não de pensadores - San Martín desaparecendo em Guayaquil. Quiroga indo numa emboscada de punhais certeiros e inevitáveis por fatalismo puro de bravata. Saraiva desdenhando uma fácil entrada vitoriosa em Montevidéu.

Porém não é na História não que a gente pode medir o traço espiritual duma gente. Um instinto artístico nobre, uma indeliberação tenaz de tragédia faz com que todo historiador pare mais ante o ocasional dum chinfrim que adiante de muitos lustros remansados e quietos de quotidianidade. As alternativas políticas também influem.

$[\ldots]$

Consideremos nossa lírica crioula. Tudo nela é quietude, desengano; áspero e meloso ao mesmo tempo. A veemência essencial da índole espanhola parece que assentando no pampa

Revista Letras, 
se esparramou e se perdeu. A fala se tornou mais arrastada, a igualdade dos horizontes sucessivos se riu das ambições e o rigor de sujeitar um mundo montanhoso se engruvinhou nas lerdezas doces da "payada" de contraponto, do truco falador e do mate. A intensidade castelhana se abrandou mas permaneceu íntimo e vivo no crioulo esse fatalismo caçoísta pelo qual as melhores obras da literatura hispânica são duas louvações do fracasso: O Quixote na prosa e a Epístola Moral no verso. Sofrimento, añoranzas mansas, pândega maliciosa e sossegada são motivos eternos da nossa lírica popular. Não possui assombro de metáfora não; a imagem entremostrada não se acaba. (...)

A tristura, a caçoada imóvel, a carapuça irônica são mesmo os únicos aspectos que uma arte crioula pode apresentar sem sangue estranho. Lugones está muito bem no "Solteirão" ou na "Quimera Lunar" mas vai muito mal na altiloquência de assustador involuntário de leitores porém. Quanto a gritalhões que nem Ricardo Rojas, feitos de espuma patriotadas e nada insondável, são a vergonha paradoxal da verdadeira maneira de ser da gente. O público sente isso e sem se meter ajuizando da obra dele, a deixa de lado prudentemente, antevendo como razão que ela tem muito mais de grandioso que de legível. Ninguém não terá coragem pra imaginar que em Fernández Moreno tem mais valor que em Lugones porém toda alma da gente se afina melhor com a serenidade daquele que com o gongorismo árduo deste.

Lugones (...) é o exemplo menos lastimoso do transe por que passamos todos agora: o do crioulo que procura desacrioular-se pra vencer no século. A tragédia dilemática dele é a da gente; o triunfo dele a exceção de muitos fracassos.

O quieto desgoverno de Rosas se perdeu; os trens-de-ferro valorizaram campo; uma enganadora e mesquinha agricultura empobreceu a criação fácil e o crioulo, tornando estranho dentro da própria pátria compreendeu sofrendo a significação hostil das palavras "argentinidade" e "progresso". Nenhum cabalista prolixo, numerador de letras não rendeu pra nenhuma palavra a reverência que nós rendemos a essas duas. É culpa delas que as plantações encarcerem o pampa, que a gauchagem se tenha abatido, que os ofícios únicos do crioulo sejam polícia, vagabundagem ou a vilania de que a nossa cidade se chama Babel. No poema de Hernández e nas 


\section{Antelo, R. A tradução infinita}

Revista Letras,

Curitiba, UFPR, n. 95 182-202, jan./jun. 2017. ISSN 2236-0999 (versão eletrônica)

narrativas bucólicas de Hudson, estão os primeiros atos da tragédia crioula.

Faltam os seguintes cujo palco é a planura sem parada e a visão linear de Buenos Aires, inquietada pelo movimento. Já a República nos estrangeiriza e se perde. O crioulo fracassa porém a pátria se altiva e se insolenta. Tem bandeiras no vento e talvez qualquer dia, à força de matanças, nos intrometeremos a civilizadores do continente. Seremos uma nação macanuda. Por causa dessa proceridade de militar nossos maiores serão claros ao olho do mundo. Si não houver nenhum, se inventa! Terá prêmios pro passado também. Confiemos, leitor, que se lembrem da gente nessa distribuição justa de glória...

Morrer é lei de raças e indivíduos. Se deve de morrer bem, sem exagero de queixa, sem pretender que o mundo perca seu sabor por causa disso e com uma caçoada bem bonita na boca. Estou lembrando Santos Vega... E com uma finalidade que ainda não tinha percebido nele. Morrer cantando.

JORGE LUIS BORGES

(Inquisiciones $^{6}$ )

(Trad. Mário de Andrade in Diário Nacional, São Paulo, 13 maio 1928).

Pois bem, como assinalou recentemente, e de maneira exemplar, Delfina 193 Muschietti ${ }^{7}$, os leitores-receptores devemos sempre aguçar nossa capacidade para ler essa singularidade irredutível que é um autor ${ }^{8}$, ativando uma caixa de ressonância que capte intensidades da repetição no texto, ou seja, formas fantasmáticas que vão e vem entre várias posições móveis (a de escritor, a de crítico-tradutor-escritor), formas que, entre elas, se intersectem de maneira variada e se ponham, por sua vez, em contato com diferentes horizontes culturais e diversas sensibilidades frente à língua. Como leitor-crítico, Mário de Andrade realiza essa operação com a queixa de Borges e se defronta assim com um estado muito peculiar do castelhano do Prata reconfigurado pelos martinfierristas, mas também se depara com um estado da norma literária e poética muito semelhante ao que então se discutia no Brasil (daí que, em seu exemplar da obra, trace uma nota marginal, no começo da inquisição, com o sintomático significante "Brasil”)

6 ANTELO, Raul - Na ilha de Marapatá (Mário de Andrade lê os hispanpos-americanos). São Paulo, Hucitec/INL, Fundação Nacional Pró-Memória,1986, p.224-229.

7 CF. MUSCHIETTI, Delfina - "La traducción entre forma y fantasma: el escritor-crítico-traductor en el cruce de horizontes culturales". Fala apresentada no Congreso de Teoria Literaria Orbis Tertius, Universidad de La Plata, maio 2006; "Las traducciones de Rimbaud en el Río de la Plata”. Conferência na Aliança Francesa de Buenos Aires, junho 2006. 8 Cf. FERRARI, Federico \& NANCY, Jean-Luc - Iconographie de l'auteur. Paris, Galilée, 2005. 
e por isso mesmo se defronta com inusitadas, ainda que familiares, relações com contextos sociais e culturais que envolvem corpos, gêneros, subjetividades, memórias, às quais ele deve poder formar novamente, mas agora desalojadas, deslocadas, em outro lugar. Não em vão, em um poema esquecido em um dos números da vanguardista Klaxon, o "Poema abúlico", Andrade confessa ter pena dos homens mais infelizes do mundo, os que não sabem se na verdade são turcos ou gregos, franceses ou alemães. "Nem sabem a quem pertence a ilha de Martim Garcia!...” - tema que, nesse relato de identidade abúlica que é Macunaíma, se traduzirá como identidade abandonada na ilha de Marapatá.

Mário de Andrade parte, então, desse ponto vertiginoso - a identidade, o mesmo - para se deixar tomar pela voz de um Borges orillero e gongórico, por essa respiração, por esse estado peculiar do idioma dos argentinos. Como bom músico", Mário de Andrade é fiel ao tom, ao fantasma da repetição, um tom anterior, inclusive, à língua de origem. Quer escutar uma estranheza que se lhe gruda e se desprende, consciente de que o relevante em um texto é ler o que está armado, de fato, em seu discurso e, a partir desse dado imanente da forma, construir os sentidos e os desvios que nos levam de um contexto cultural a outro, mais amplo. Não se trata, portanto, nos diz Muschietti, de ser ou não literal. Antes, trata-se de ser fiel a essa estranheza que deriva da repetição mesma. Por isso Mário traduz o destino, mais que manifesto, resignado, de "Seremos una fuerte nación”, à maneira oral, do tango ouvido nas rádios paulistas, como "Seremos uma nação macanuda", onde reaparece o elemento criollo da macana - criollo pouco importa se por ser taíno ou tupi, já que em ambos os casos o sentido é o mesmo, porrete. O macanudo - o criollo - é, então, embora indizível, um ictus sententiarum que se pode traduzir a outros estratos da mesma língua (o bamoarrebentá).

Mário de Andrade passa assim a um segundo momento da operação de tradução. Ali, o leitor-crítico devém escritor-doador de forma. Da materialidade da inquisição primeira só conservamos, na versão de Andrade, um resto, o fantasma criollo, que ressoa, como próprio, em nosso ouvido, o fantasma de sua repetição, que é sua singularidade irredutível, mas não intransferível. Haverá que lhe dar, então, uma nova forma em português, uma forma sob a égide da gramatiquinha da fala brasileira, que ele também teoriza à mesma época. Só que se trata, como também disse Benjamin, de uma forma derivada ou segunda, o que não aponta em nada para uma sacralização do original, em detrimento da tradução, senão que se trata, na verdade, de uma profanação ou sacrilégio, ou seja, uma recomposição inicial do fantasma da repetição, para a seguir o tradutor se retrair até tornar-se quase invisível.

$\mathrm{O}$ tradutor deve produzir então uma imago, mais que uma imagem, um contato por esvaziamento, uma imagem ausente, uma imagem do ausente,

9 Andrade havia publicado, em 1925, um ensaio de Estética, A Escrava que não é Isaura (onde já teoriza sobre a polifonia do texto moderno) e pouco depois, em 1928, o Ensaio sobre a Música Brasileira. 
Antelo, R. $A$ tradução infinita

alojando na repetição tradutora, algo desse fantasma destacado da repetição primeira. Uma Nachleben, diria Aby Warburg, uma potência que estava, no criollo de Borges, esperando para se reencarnar, no crioulo de Andrade, por oposição à economia da equivalência ou do intercâmbio, segundo uma economia do roubo e da diferença. Capta-se então, nesse exercício, não exatamente a equivalência entre línguas, que é completamente inexistente, mas sim as ambivalências inerentes a todo valor - as aproximações oblíquas, os choques, a expansão de conotações que se irradiam, quase sem querer, para além do original - e que Mário, como tradutor, estava em condições de controlar. Basta pensar no sentido sintético-nacional do criollo e no matiz etno-discriminatório do crioulo. É á, argumenta Muschietti, onde o tradutor se reencontra com a vertigem e se torna equilibrista, um minucioso técnico da repetição diferida.

Es allí cuando gana y cuando pierde. Un luminoso fracaso, sabido de antemano y que igual no obstaculiza el afán de traducir. Y en tanto el traductor mantenga la decisión de no neutralizar el texto de partida, respetar ambigüedades e impactos, llegará al objetivo deseado: mantener abierta la más abierta de las formas (...). Igualmente, la traducción en tanto implica una lectura del original, forma parte de su crítica y es una expansión de la obra (...) y de algún modo, la cierra. El desafío del traductor es que ese cierre sea apenas como un temblor: esa levedad está sustentada, sin embargo, por intensas investigaciones de las formas de la lengua, trabajo con diccionarios múltiples, despliegue de posibilidades.

Aplicando à tradução as ideias que Georges Didi-Huberman vem trabalhando em Venus rasgada, Diante do tempo e $A$ imagem sobrevivente, poderíamos dizer que o tradutor-invisível trabalha minuciosamente para respeitar uma forma encontrada, e ser fiel, ao mesmo tempo, a uma respiração fantasma. Essa tarefa-transferência implica opções e escolhas no elenco de palavras e giros sintáticos que sua própria língua oferece. É assim que o tradutor se torna então um investigador da língua. Da sua língua. É um momento a mais em que o tradutor se encontra com o criador. Criar é diferir. Criar é tornar-se estranho à própria língua, desgeograficar-se, como irá teorizar o mesmo Andrade, no prefácio a Macunaima, ou descriollarse, como prefere Borges, para então começar a escrever e, em um momento específico e inerente à tarefa de traduzir, alojar, no português moderno da experimentação, algo do espanhol gongórico de Borges, permitindo que este violente seu português, tão babélico como o portenho. Por último, quando, como neste caso, comparamos traduções, nos diz Muschietti que passamos a um terceiro patamar, mais uma vez situados no lugar de leitores-críticos.

Revista Letras,

Curitiba, UFPR, n. 95 182-202, jan./jun. 2017. ISSN 2236-0999 (versão eletrônica) 
Si la tarea del traductor responde a determinadas elecciones, en esta posición tercera podremos apreciar los modos en que el horizonte cultural y retórico de cada escritor-traductor (esto es, su forma de leer, su orientación en el campo estético e intelectual al que pertenece) ha velado ciertas intensidades del original, y ha guiado en otra dirección las elecciones en el momento de traducir. ${ }^{10}$

Mas, se é verdade que "esa reverencia del yo, de la irreemplazable diferenciación humana que es cualquier yo, justifica la literalidad en las traducciones", chegados a este umbral de abstração nos inclinamos a pensar que quem melhor compreendeu a tarefa de profanar o original borgeano foi Clarice Lispector. Mário de Andrade havia ensaiado sua paródia modernista no eu arlequinal de Pauliceia desvairada; mas é Lispector quem, como diz Agamben, interrompe, mediante sua presença incongruente e estranha, as vicissitudes que se desenvolvem na cena modernista, e desfaz a trama canônica com a chacota do Arlequim.

É verdade que, atendendo às solicitações do mercado, a escritora empreendeu essa tarefa tradutora em muitas outras oportunidades, voltando a contar as viagens de Gulliver ou simples relatos de Walter Scott ou Jack London. Mas o caso de Borges é diferente e nos chama a atenção porque Borges vive, em Clarice, com maior intensidade que em Mário. Basta considerar para isso a estratégia que a escritora empreende, em sua coluna e no Jornal do Brasil, para traduzir uma página ultraconhecida de Borges.

\section{Borges y yo}

Al otro, a Borges, es a quien le ocurren las cosas. Yo camino por Buenos Aires y me demoro, acaso ya mecánicamente, para mirar el arco de un zaguán y la puerta cancel; de Borges tengo noticias por el correo y veo su nombre en una terna de profesores o en un diccionario biográfico. Me gustan los relojes de arena, los mapas, la tipografía del siglo XVIII, las etimologías, el sabor del café y la prosa de Stevenson; el otro comparte esas preferencias, pero de un modo vanidoso que las convierte en atributos de un actor. Sería exagerado afirmar que nuestra relación es hostil; yo vivo, yo me dejo vivir, para que Borges pueda tramar su literatura y esa literatura me justifica. Nada me cuesta confesar que ha logrado ciertas páginas válidas, pero esas páginas no me pueden salvar, quizá porque lo bueno ya no es de nadie, ni siquiera del otro, sino del lenguaje o

10 Cf. MUSCHIETTI, Delfina - "La traducción entre forma y fantasma: el escritor-crítico-traductor en el cruce de horizontes culturales", op. cit. 
Antelo, R.
A tradução
infinita

la tradición. Por lo demás, yo estoy destinado a perderme, definitivamente, y sólo algún instante de mí podrá sobrevivir en el otro. Poco a poco voy cediéndole todo, aunque me consta su perversa costumbre de falsear y magnificar. Spinoza entendió que todas las cosas quieren perseverar en su ser; la piedra eternamente quiere ser piedra y el tigre un tigre. Yo he de quedar en Borges, no en mí (si es que alguien soy), pero me reconozco menos en sus libros que en muchos otros o que en el laborioso rasgueo de una guitarra. Hace años yo traté de librarme de él y pasé de las mitologías del arrabal a los juegos con el tiempo y con lo infinito, pero esos juegos son de Borges ahora y tendré que idear otras cosas. Así mi vida es una fuga y todo lo pierdo y todo es del olvido, o del otro.

No sé cuál de los dos escribe esta página.

Observe-se, em primeiro lugar, que Clarice traduz "Borges y yo" tomando partido sobre o gênero, sobre o gender, sobre a origem, sobre a classificação. O texto é então "Uma 'prosa' de Jorge Luis Borges”, prosa entre aspas, que sintomaticamente delatam distância ou alheamento com relação a essa categoria. A mesma distância com que Clarice tampouco escreve "romances" para rotular seus textos. Abaixo, a versão, mais ou menos convencional, da escritora.

\section{Borges e eu}

Ao outro, ao Borges, é a quem ocorrem as coisas. Eu caminho por Buenos Aires e me demoro, talvez já mecanicamente, a olhar o arco de um saguão ou um portão de ferro: de Borges tenho notícias pelo correio e vejo meu nome escrito em uma comissão de professores ou num dicionário biográfico. Agradam-se os relógios das praças, os mapas, a tipografia do século XVIII, o sabor de café e a prosa de Stevenson: o outro compartilha dessas preferências, mas de um modo vaidoso que as converte em atributos de ator. Seria exagerado afirmar que nossa relação é hostil: eu, vivo, eu me deixo viver para que Borges possa tramar sua literatura e essa literatura me justifica. Nada me custa confessar que tem conseguido páginas válidas, mas essas páginas não podem me salvar talvez porque o bom já não é de ninguém nem se quer do outro, se não da literatura ou da tradição. Por outro lado, já estou destinado a perder-me, definitivamente, e só algum instante de mim poderá sobreviver ao outro. Pouco a pouco vou cedendo-lhe tudo, ainda que conheça seu perverso costume de falsear e engrandecer. Spinosa entendeu que todas as coisas querem perseverar em

Revista Letras, Curitiba, UFPR, n. 95 182-202, jan./jun. 2017. ISSN 2236-0999 (versão eletrônica) 
seu ser: a pedra eternamente pedra quer ser pedra e o tigre um tigre. Eu hei de permanecer em Borges, não em mim (se é que sou alguém), mas menos em seus livros que em muitos outros momentos ou do que no ponteio de uma guitarra.

Há muitos anos eu tratei de livrar-me dele e passei das mitologias do bairro aos jogos com o tempo e números, e com o infinito, mas esses jogos são de Borges agora e terei de imaginar outras coisas. Assim minha vida é uma fuga e tudo tenho perdido e tudo é do esquecimento ou do outro.

Não sei qual dos dois escreve esta página.

(Do livro El Hacedor, de JLB).

Repare-se, porém, que assumindo, como em $A$ paixão de $G H$, o final do antecedente, "não sei qual dos dois escreve esta página", como início do fragmento consequente, poderíamos pensar que Clarice agrega um suplemento a essa "tradução", obedecendo também à premissa da atribuição errônea, uma regra central da poética de Borges. Com o corpo solto, continua então o texto, suplementa-o, transborda-o e o liquida porque, simplesmente, lhe adere uma prótese.

E agora vamos ao que há de mais velho e permanente e teimoso do mundo: Números - disse teimoso porque nada consegue modificá-los. Não há nada para atrapalhar-lhes a carreira, através dos tempos, numa semântica. O número é como o destino, sim, um desafio a tudo. Ele simplesmente é. Não há nascimento, nem vida, nem morte do número. É uma norma, uma lei, um ritmo.

Para Pitágoras o número é esta ordem, esta coerência que transmite a idéia de uma tensão de um todo, o kosmos oposto ao kaos, embora este termo não deva ser entendido no seu sentido vulgar, mas no do que ele é um pré-kosmos, onde estão contidas todas as possibilidades do vir-a-ser-kosmos. Todas as coisas, pelo menos as que são conhecidas, tem número, pois não é possível que uma coisa qualquer seja pensada ou conhecida sem número.

Já lhe disse hoje que o número possui duas formas próprias: o ímpar e o par. A combinação dessas duas formará uma terceira: o par-ímpar. A paridade é infinita à nossa volta e através dela podemos com-parar. Ao passo as coisas ímpares são menos incom-paráveis. Aqui estamos em pleno caminho para descobertas maravilhosas. A unidade suprema - o um, que não é número, pois nele não há participação...

(El hacedor, de JLB). 
Antelo, R. A tradução infinita

Revista Letras, Curitiba, UFPR, n. 95 182-202, jan./jun. 2017. ISSN 2236-0999 (versão eletrônica)
Obviamente, o texto não é de Borges, nem mesmo de JLB, personagem afinado, por seu laconismo, com GH. O texto é absolutamente clariceano e nos ilustra que o próprio do número é distribuir-se no espaço liso, que já não se divide sem mudar de natureza ou sem mudar de unidade, o que representa uma distância e não uma grandeza, uma lateralidade e não uma literalidade. Numero Deus impare gaudet - dizia Virgílio (Eglogas, VIII, 75). Deleuze e Guattari nos ensinaram, nesse sentido, que o número é articulado, nômade, direcional, ordinal, um número numerante que remete ao espaço liso, da mesma maneira que o número numerado remete ao espaço estriado. Clarice sabe disso e por isso ativa um texto multifocal: o faz dizendo que essa versão já é número, é número dois, mas, ainda é unidade. É outra mas anuncia o mesmo. Ainda que não seja o mesmo número nas duas versões, nem a mesma unidade, nem a mesma maneira de dividir-se essa hipotética unidade. Ou seja, o exercício de Clarice é uma espécie de manifesto da literatura menor, aquela que, segundo seus criadores, "nunca deixará de enriquecer a maior, comunicando-lhe sua intuição, seu andamento, sua itinerância, seu sentido e seu gosto pela matéria, pela singularidade, pela variação, pela geometria intuicionista e pelo número numerante"11.

Mas há algo mais. Não se trata de opor, linearmente, as multiplicidades lisas ou nãométricas, às métricas, perguntando-se como pode uma determinação ser capaz de fazer parte de outra sem que se possa lhe designar nem grandeza exata nem unidade comum, nem diferença diante da situação. Há outro aspecto da questão, talvez ainda mais importante, e é que o próprio acontecimento de existirem duas determinações diferentes, ainda que híbridas, exclui sua mútua comparação.

Poderíamos associar essa situação com o espaço que, em física, se chama riemanniano e que se caracteriza como radicalmente rapsódico. Em sua inquisição, Borges pretendia "puntualizar la desemejanza insuperable" que separa Borges ("o caráter verdadeiro do crioulo") e eu, o sujeito descriollado. A dessimetria é então o indício de passagem da disciplina moderna ao controle como caos. Do mesmo modo, o filósofo matemático Albert Lautman, autor de um pioneiro estudo sobre simetria e dessimetria no pensamento científico (tema também muito caro a Roger Caillois, autor de um texto de 1970 com esse título ${ }^{12}$ ), Lautman, dizíamos, escreve, em 1942, a pedido de François Le Lionnais, uma colaboração para um volume sobre matemática e filosofia, quando Le Lionnais ainda se encontrava no campo de concentração de Dora, texto que só publicaem 1948, na revista de poesia Cahiers du Sud.

11 Deleuze, Gilles; Guattari, Félix. Mil platôs - capitalismo e esquizofrenia. Tradução de Peter Pál Pelbart e Janice Caiafa. São Paulo: Editora 34, 1997. p. 193.

12 CAILLOIS, Roger - "La disymetrie" in Coherences aventureuses. Paris Gallimard, 1973. O mesmo Caillois assinala que suas ideias nesse texto reescrevem a noção do sagrado e da transgreção, como aspectos da teoria da festa, que ele mesmo havia desenvolvido em seus livros O mito e o homem e O homem e o sagrado. Este ultimo havia sido antecipado, fragmentariamente, nas páginas de Sur e, em grande medida, se deve a um desacordo com Borges a respeito do hipertexto. Cfr. ANTELO, Raul - "Notas performativas sobre el delito verbal" in Variaciones Borges, $\mathrm{n}^{\circ}$ 2, Aarhus (Dinamarca), 1996. 
François Le Lionnais e Raymond Queneau eram donos de um restaurante, o Vrai Gascon, onde nasceu o OULIPO, como braço do Colégio Patafísico. Pois bem, Le Lionnais não hesitou em convidar seu sócio a colaborar nesse dossiê sobre matemática e filosofia, de modo que não é fortuito então que, em "Une traduction en joycien”, ensaio compilado em Batons, chiffres et lettres (1950), Queneau parta de uma frase banal, digna de um restaurateur ("Drôle de vie, la vie de Poisson”) para fornecer a partir dela um espaço riemanniano, o do campo de concentração, onde nos deparamos com a vida nua, "Doradrôle de vie, la vie de poisson".

Antes da guerra, no entanto, em Les schémas de structure (1938), já esclarecia o amigo comum Albert Lautmann que

os espaços de Riemann são desprovidos de qualquer espécie de homogeneidade. Cada um deles é caracterizado pela forma da expressão que define o quadrado da distância entre dois pontos infinitamente próximos. (...). Disso resulta que dois observadores vizinhos podem referir, num espaço de Riemann, os pontos que estão em sua vizinhança imediata, mas não podem, sem uma nova convenção, situar-se um em relação ao outro. Cada vizinhança é, pois, como uma pequena porção de espaço euclidiano, mas a ligação de uma vizinhança à vizinhança seguinte não está definida e pode ser feita de uma infinidade de maneiras. O espaço de Riemann mais geral apresenta-se, assim, como uma coleção amorfa de porções justapostas, que não estão atadas umas às outras. ${ }^{13}$

Deleuze retoma essa bela descrição de Lautman, a cita (a liquida), em Mil platôs, para dizer que é possível definir esta multiplicidade independentemente de qualquer referência a uma métrica, por simples condições de frequência ou melhor de acumulação válidas para vários entornos, condições completamente distintas das que determinam os espaços métricos e seus respectivos cortes, o que o leva a concluir que o espaço riemanniano é um puro patchwork.

Tem conexões ou relações táteis. Tem valores rítmicos que não se encontram em outra parte, ainda que possam ser traduzidos num espaço métrico. Heterogêneo, em variação contínua, é um espaço liso enquanto amorfo, não homogêneo. Definimos, pois, um duplo caráter positivo do espaço liso em geral: de um lado, quando as determinações que fazem parte uma da outra remetem a distâncias envolvidas ou a diferenças ordenadas, independentemente da grandeza; de outro lado,

13 Apud Deleuze, Gilles; Guattari, Félix. Mil platôs - capitalismo e esquizofrenia. Tradução de Peter Pál Pelbart e Janice Caiafa. São Paulo: Editora 34, 1997. p. 193-4. 
Antelo, R.
A tradução
infinita quando surgem determinações que não podem fazer parte uma da outra, e que se conectam por processos de frequências ou acumulação, independentente da métrica. São os dois aspectos do nomos do espaço liso. ${ }^{14}$

Digamos, entre parênteses, que a tactilidade, desde Carl Einstein em diante, é característica da arte negra, crioula, totalmente Outra. Acrescentemos, também, que Deleuze igualmente nos advertia que se de fato há uma necessidade dissimétrica de passar do liso ao estriado, há também compulsão simétrica de passar do estriado ao liso, o que implica admitir que, se de um lado, a geometria itinerante e o número nômade dos espaços lisos não cessam de inspirar a ciência real do espaço estriado, inversamente, a métrica dos espaços estriados (metron) é indispensável para traduzir os estranhos elementos de uma multiplicidade lisa. E nesse ponto o filósofo nos dá a chave da tradução infinita.

Ora, traduzir não é um ato simples; não basta substituir o movimento pelo espaço percorrido, é preciso uma série de operações ricas e complexas (e Bergson foi o primeiro a dizê-lo). Tampouco é um ato secundário. Traduzir é uma operação que, sem dúvida, consiste em domar, sobrecodificar, metrificar o espaço liso, neutralizá-lo, mas consiste, igualmente, em proporcionar-lhe um meio de propagação, de extensão, de refração, de renovação, de impulso, sem o qual ele talvez morresse por si só: como uma máscara, sem a qual não poderia haver respiração nem forma geral de expressão. ${ }^{15}$

É essa máscara do neutro, esse sopro de vida nua, essa prótese, mote de reflexão para o nietzschianismo francês de entre-guerras, quer se chame Bataille ou Duthuit, Caillois ou Leiris, aquilo com o qual Clarice vem a suplementar a queixa (neurótica) da identidade nacional não-toda. Ali se joga a aventura da passagem de uma modernidade lisa e homogênea a outra modulação, estriada ou heterogênea, ou seja, a uma hipermodernidade, aquela do nosso ineludível presente.

Revista Letras,

14 Deleuze, Gilles; Guattari, Félix. Mil platôs - capitalismo e esquizofrenia. Tradução de Peter Pál Pelbart e Janice Caiafa. São Paulo: Editora 34, 1997. p. 194.

15 Deleuze, Gilles; Guattari, Félix. Mil platôs - capitalismo e esquizofrenia. Tradução de Peter Pál Pelbart e Janice Caiafa. São Paulo: Editora 34, 1997. p. 194-5.

Curitiba, UFPR, 


\section{Referências}

ANTELO, Raul - Na ilha de Marapatá (Mário de Andrade lê os hispanpos-americanos). São Paulo, Hucitec/INL, Fundação Nacional Pró-Memória, 1986.

ANTELO, Raul - "Notas performativas sobre el delito verbal" in Variaciones Borges, $\mathrm{n}^{\circ}$ 2, Aarhus (Dinamarca), 1996.

BORGES, Jorge Luis - "Las dos maneras de traducir" in Textos recobrados 1919-1929, Barcelona, Emecé Editores, 1997.

BORGES, Jorge Luis - "Queja de todo criollo" in Inquisiciones. Buenos Aires, Proa, 1925.p.131-138.

CAILLOIS, Roger - "La disymetrie" in Coherences aventureuses. Paris Gallimard, 1973.

DELEUZE, Gilles; Guattari, Félix. Mil platôs - capitalismo e esquizofrenia. Tradução de Peter Pál Pelbart e Janice Caiafa. São Paulo: Editora 34, 1997.

FERRARI, Federico \& NANCY, Jean-Luc - Iconographie de l'auteur. Paris, Galilée, 2005.

MUSCHIETTI, Delfina - "La traducción entre forma y fantasma: el escritor-crítico-traductor en el cruce de horizontes culturales". Fala apresentada no Congreso de Teoria Literaria Orbis Tertius, Universidad de La 202 Plata, maio 2006.

MUSCHIETTI, Delfina -"Las traducciones de Rimbaud en el Río de la Plata". Conferência na Aliança Francesa de Buenos Aires, junho 2006.

VALLEJO, Antonio - "Criollismo y metafísica". Martin Fierro, n 27-8, 10 mayo 1926, p.17.

Submetido em: 24/11/2016

Aceito em: 22/12/2016 